\title{
MORPHOMETRIC EVALUATION OF GLENOID CAVITY AND OTHER DIMENSIONS OF DRY HUMAN SCAPULAE
}

\section{Krishna Gopal *1, Anurag Singh ${ }^{2}$, Onkar Singh ${ }^{3}$, Chanchal Sharma 4.}

${ }^{* 1}$ Associate Professor, Department of Anatomy, Sri Guru Ram Rai Medical College and Hospital, Patel Nagar, Dehradun. Uttaranchal, India.

${ }^{2}$ Professor and Head, Department of Anatomy, Sri Guru Ram Rai Medical College and Hospital, Patel Nagar, Dehradun. Uttaranchal, India.

${ }^{3}$ Demonstrator, Department of Anatomy, Sri Guru Ram Rai Medical College and Hospital, Patel Nagar, Dehradun. Uttaranchal, India.

${ }^{4}$ Tutor, Department of Anatomy, Sri Guru Ram Rai Medical College and Hospital, Patel Nagar, Dehradun. Uttaranchal, India.

\section{ABSTRACT}

Introduction: The scapula (shoulder blade) is a triangular flat bone that lies on the posterolateral aspect of the thorax. The scapula bears various angles namely superior, inferior, lateral, medial, acromial and coracoid angle. The three borders meet strategically to form the referenced three angles (lateral, superior, and inferior. Its lateral angle, truncated and broad, bears the glenoid cavity which articulates with the head of the humerus at the glenohumeral joint. The morphology of the glenoid cavity is highly variable. The glenoid rim presents a notch in its upper and front part

Materials and Methods: This study included thorough observation of 120 dry human scapulae, 67 from left side and 53 from right side, obtained from department of Anatomy, Sri Guru Ram Rai Institute of medical and health sciences Dehradun following standard guidelines. All the metric and non metric parameters were observed and recorded in tabulated form.

Results: The mean length of scapula of left side was observed as $127.35 \pm 12.35$ and right side was $128.10 \pm 11.21$.The total mean value for length of scapula was noted as $130.21 \pm 12.65$. The mean breadth of scapula was recorded as $96.98 \pm 7.62 \mathrm{~mm}$. The mean value of scapular index was listed as $68.47 \pm 3.98$. The mean of infraspinous length was recorded as $99.14 \pm 9.54$ and the infraspinous index was $99.65 \pm 8.32$.The mean AP glenoid diameter 1 was $24.54 \pm 2.65 \mathrm{~mm}$, the mean AP glenoid diameter 2 was $16.56 \pm 2.45 \mathrm{~mm}$ and the mean AP glenoid diameter 3 was $17.09 \pm 2.75$ The shape of the glenoid cavity was recorded as type 1 (oval) $17.50 \%$, Type2 (pear) $48.14 \%$, Type3(inverted coma) and Type4(other).

Conclusion: To summarize, the present study provides a base line data of different scapular dimensions on the left and right sides. Knowledge of the measurements and indices of various parameters of scapula such as length, width and various parameters of glenoid cavity can be used for comparative anatomy and also for defining the race.

KEY WORDS: Scapular index, glenoid notch, infraspinous length.

Address for Correspondence: Dr. Krishna Gopal, Associate Professor, Department of Anatomy, Sri Guru Ram Rai Medical College and Hospital, Patel Nagar, Dehradun. Uttaranchal, India.

E-Mail: dr.krish2007@gmail.com

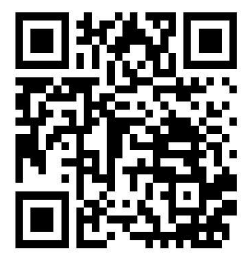

DOI: $10.16965 /$ ijar.2018.199 \section{IC} International Journal of Anatomy and Research ICV for 2016 ISSN (E) 2321-4287 | ISSN (P) 2321-8967 90.30 https://www.ijmhr.org/ijar.htm DOI-Prefix: https://dx.doi.org/10.16965/ijar

Article Information

Received: 24 Mar 2018

Peer Review: 24 Mar 2018

Revised: None
Accepted: 08 May 2018

Published (0): 05 Jun2018

Published (P): 05 Jun 2018 


\section{INTRODUCTION}

The scapula (shoulder blade) is a triangular flat bone that lies on the posterolateral aspect of the thorax, overlying the 2 nd to 7 th ribs. The convex posterior surface of the scapula is unevenly divided by the spine of the scapula into a small supraspinous fossa and a much large infraspinous fossa. The concave costal surface of the scapula has a large subscapular fossa. It has a triangular spine, its continuation the acromion process and the coracoid process. The scapula bears various angles namely superior, inferior, lateral, medial, acromial and coracoid angle. Superior angle It was measured as the angle where the superior border meets the medial or the vertebral border of the scapula [1].

Inferior angle: It was measured as the angle where the medial or the vertebral border of the scapula meets the lateral or the axillary border.

Lateral angle: It was measured as an open angle where the superior and the lateral or the axillary borders are wedged by the glenoid fossa.

Medial angle: It was measured as the angulation of the bone formed at the medial end of the anterior border of the crest of the spine of the scapula where the plate like body of the bone is bent between the medial borders of the supraspinous and the infraspinous fossae.

Acromion angle: It was measured as the angle where the lower border of the crest of the spine becomes continuous with the lateral border of the acromion process.

Coracoid angle: It was measured as the angle formed where the root of the coracoid process is bent sharply so as to project forward and slightly laterally. The body of the scapula is enclosed by the superior, medial, and lateral borders. The superior border is the shortest and the sharpest of the three borders and it ends at the scapular notch [2]. The medial border, also called the vertebral border, is the longest of the three borders; it exhibits either a concave, convex, or straight pattern The three borders meet strategically to form the referenced three angles $[3,4]$.

Its lateral angle, truncated and broad, bears the glenoid cavity which articulates with the head of the humerus at the glenohumeral joint and may be regarded as the head of the scapula. The morphology of the glenoid cavity is highly variable. The glenoid rim presents a notch in its upper and front part [5]. Due to presence of this glenoid notch, various shapes of glenoid cavity are found like pear-shaped, oval or inverted comma shaped $[6,7]$. The knowledge of various dimensions of the scapula may be helpful in open reduction and internal fixation of significantly displaced scapular fractures [8].

\section{MATERIALS AND METHODS}

The present study has been carried out on 120 dry human scapulae, which were collected from the department of Anatomy, Sri Guru Ram Rai Institute of medical and health sciences Dehradun. The macerated scapulae were randomly selected. The scapulae did not present with any external deformity. The age and sex of the scapulae were not taken into consideration. Out of the 120 scapulae 67 belongs to the left side and 53 to the right side. Each scapula was carefully examined for the shape of the glenoid cavity, its anterior and posterior margins and notches. Each scapula was also examined for its length, breadth, and other parameters. Presence of any accessory foramen. The photographs were taken by the Sony digital camera and anatomical parameters measured with the help of sliding digital Vernier caliper. All The measurements were recorded in millimeters. Each parameters was defined as follows:

Scapular length: Maximum vertical measurement from superior angle to inferior angle(A-B)

Scapular breadth: Measurement from angle at the medial border(point $C$ ) to the middle of the posterior border to glenoid cavity(D).

Infraspinous length: Measurement from point $C$ to inferior angle, point $B$.

Length of spine: Measurement from angle at the medial border(point C ) to the lateral border of acromian process(E).

Scapular index: (Breadth/length) $\times 100$

Infraspinous index: (Breadth/Infraspinous length) $\times 100$

Glenoid cavity

Shape: The shape of the glenoid cavity was observed and recorded as follows 
Type 1(oval): The articular margin of glenoid cavity is more or less circular.

Type 2(pear): The anterior margin of glenoid cavity shows indistinct notch.

Type 3(inverted coma): The anterior margin of the glenoid cavity shows distinct notch.

Type 4(other): More or less recognizable glenoid notch at the both anterior and posterior margin of the glenoid cavity.

Maximum vertical diameter: Measured from supraglenoid tubercle to inferior glenoid margin (A-B).

Anteroposterior glenoid diameter 1: Maximum width of articular margin of glenoid cavity(C-D).

Anteroposterior glenoid diameter 2: Maximum width of articular margin of glenoid cavity at the glenoid notch (E-F).

Anteroposterior glenoid diameter 2: Represents the width of the upper half of the glenoid cavity at the midpoint between the superior margin and the mid equator $(\mathrm{G}-\mathrm{H})$.

\section{RESULTS}

The values observed were tabulated and the mean value and Range were calculated for left and right side. The mean length of scapula of left side was observed as $127.35 \pm 12.35$ and right side was $128.10 \pm 11$.21. The total mean value for length of scapula was noted as $130.21 \pm 12.65$ [Tab. 1, Fig. 2]. The mean breadth of scapula was recorded as $96.98 \pm 7.62 \mathrm{~mm}$ [Tab. 1, Fig. 2]. The scapular index was recorded I the range of $68.47 \pm 3.98$ (Left: 69.03 \pm 3.75 , Right: $67.93 \pm 4.10)$. The mean of infraspinous length was recorded as $99.14 \pm 9.54$ and the infraspinous index was $99.65 \pm 8.32$ [Tab. 1, Fig. 2]. For the glenoid cavity the mean vertical diameter was $32.08 \pm 3.09 \mathrm{~mm}$ (Left: $30.93 \pm 4.10$, Right: $31.23 \pm 3.02)$. The mean antero posterior glenoid diameter 1 was $24.54 \pm 2.65 \mathrm{~mm}$, the mean anteroposterior glenoid diameter 2 was $16.56 \pm 2.45 \mathrm{~mm}$ and the mean antero posterior glenoid diameter 3 was noted as $17.09 \pm 2.75$ [Tab. 2, Fig. 3].

The shape of the glenoid cavity was observed and recorded as type 1 (oval) $17.50 \%$, Type 2 (pear) 48.14\%, Type3 (inverted coma) and Type4 (other). [Tab. 3, Fig. 4a, 4b,4c\&4d].
Fig. 1: Showing angles of scapula and vernier caliper. SA- superior angle, MA- medial angle, IA-inferior angle, GC-glenoid cavity.

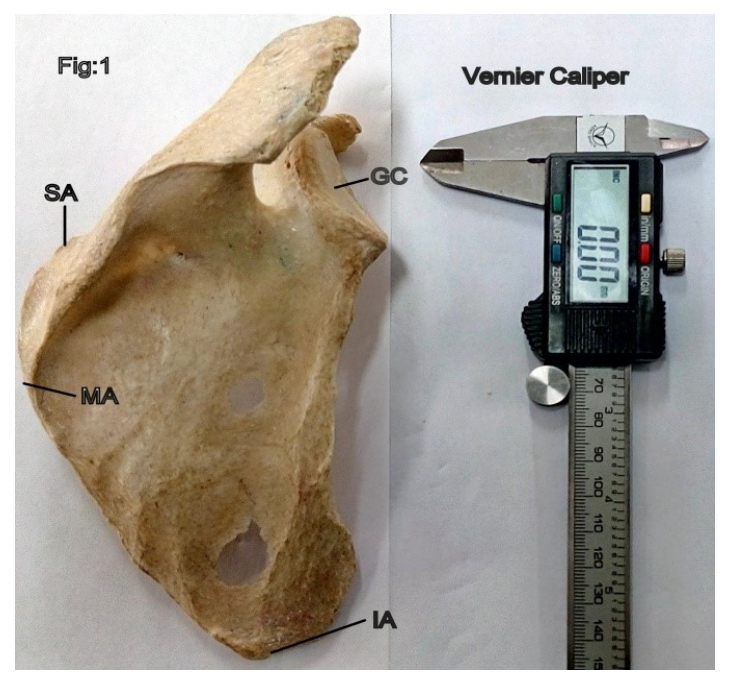

Fig. 2: Showing parameters of scapula .BC- infraspinous length, AB- length of scapula, CD-width of scapula, CF-length of spine.

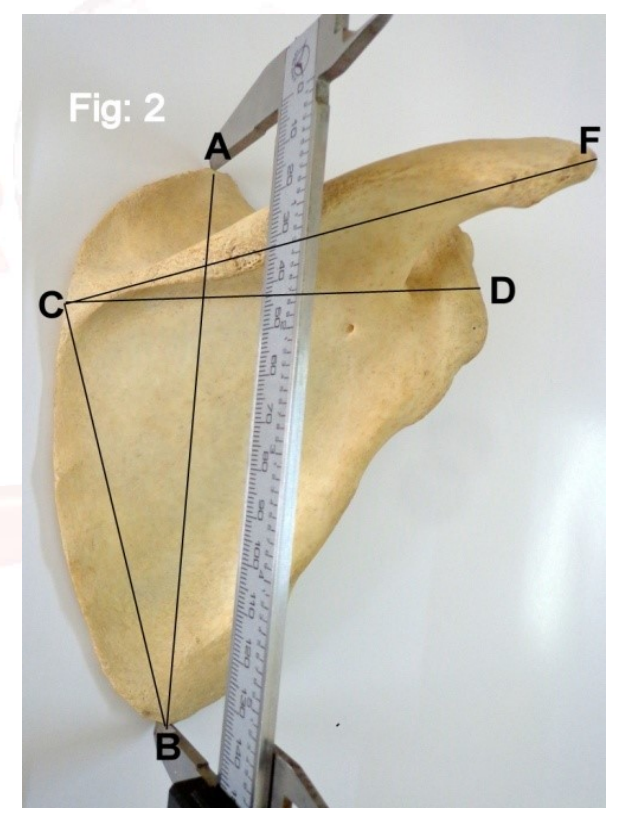

Fig 3: Showing diameters of glenoid cavity .AB-vertical length, $C D$ - anteroposterior (AP) diameter-1, EF- AP diameter-2, GH- AP diameter-3.

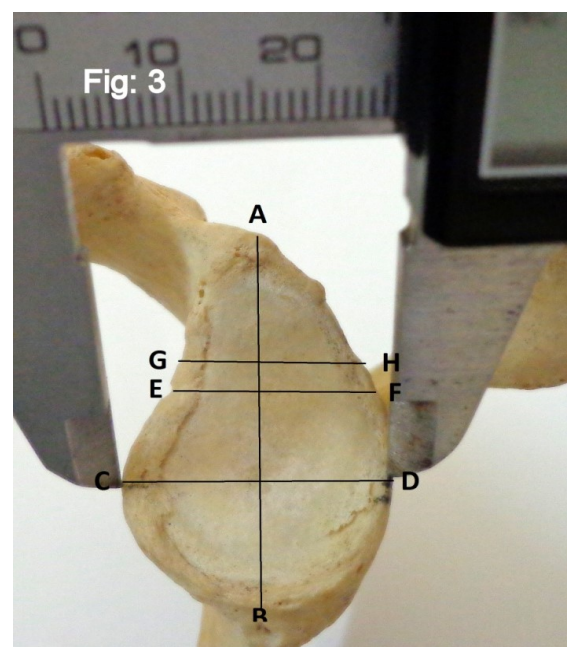


Fig 4a, 4b, 4c, 4d: Showing oval shape (Type-1), pear shape (Type-1), inverted coma shape (Type-3), \& other (Type-4) glenoid cavity.
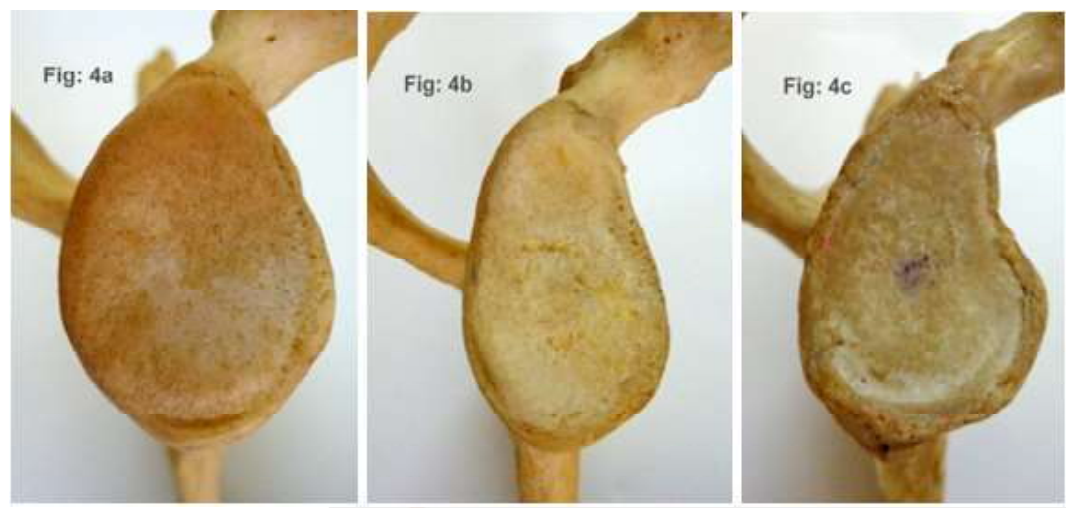

Fig. 4d

\begin{tabular}{|c|c|c|c|}
\hline Parameters & Range (mm) & Mean $\pm S D(m m)$ & $\begin{array}{c}\text { Total (Mean } \pm \text { SD) } \\
(\mathrm{mm})\end{array}$ \\
\hline $\begin{array}{l}\text { Length of } \\
\text { scapula }\end{array}$ & $\begin{array}{l}\text { Left: } 104.40-149.10 \\
\text { Right : } 105.10-150.10\end{array}$ & $\begin{array}{l}\text { Left : } 127.35 \pm 12.35 \\
\text { Right : } 128.10 \pm 11.21\end{array}$ & $130.21 \pm 12.65$ \\
\hline $\begin{array}{l}\text { Width of } \\
\text { scapula }\end{array}$ & $\begin{array}{c}\text { Left: } 82.12-110.38 \\
\text { Right : } 79.98-111.23\end{array}$ & $\begin{array}{c}\text { Left : } 95.39 \pm 7.13 \\
\text { Right : } 96.41 \pm 8.71\end{array}$ & $96.98 \pm 7.62$ \\
\hline $\begin{array}{c}\text { Scapular } \\
\text { index }\end{array}$ & $\begin{array}{l}\text { Left: } 54.29-83.76 \\
\text { Right : } 53.31-82.54\end{array}$ & $\begin{array}{c}\text { Left : } 69.03 \pm 3.75 \\
\text { Right : } 67.93 \pm 4.10\end{array}$ & $68.47 \pm 3.98$ \\
\hline $\begin{array}{l}\text { Infraspinous } \\
\text { length }\end{array}$ & $\begin{array}{c}\text { Left: } 83.27-115.30 \\
\text { Right : } 84.10-114.45\end{array}$ & $\begin{array}{c}\text { Left : } 99.54 \pm 9.76 \\
\text { Right : } 98.94 \pm 8.79\end{array}$ & $99.14 \pm 9.54$ \\
\hline $\begin{array}{l}\text { Infraspinous } \\
\text { index }\end{array}$ & $\begin{array}{c}\text { Left: } 76.87-125.98 \\
\text { Right : } 75.12-123.65\end{array}$ & $\begin{array}{l}\text { Left : } 99.89 \pm 10.12 \\
\text { Right : } 101.12 \pm 9.98\end{array}$ & $99.65 \pm 8.32$ \\
\hline $\begin{array}{l}\text { Length of } \\
\text { spine }\end{array}$ & $\begin{array}{l}\text { Left: } 98.20-140.10 \\
\text { Right : } 99.96-139.31\end{array}$ & $\begin{array}{l}\text { Left : } 118.10 \pm 10.59 \\
\text { Right : } 119.21 \pm 9.98\end{array}$ & $118.89 \pm 10.10$ \\
\hline Parameters & Range (mm) & Mean $\pm S D(m m)$ & $\begin{array}{c}\text { Total } \\
\text { (Mean } \pm S D) \\
(\mathrm{mm})\end{array}$ \\
\hline $\begin{array}{c}\text { Vertical Glenoid } \\
\text { Diameter(AB) }\end{array}$ & $\begin{array}{l}\text { Left: } 25.10-36.33 \\
\text { Right : } 26.32-35.14\end{array}$ & $\begin{array}{l}\text { Left : } 30.93 \pm 4.10 \\
\text { Right : } 31.23 \pm 3.02\end{array}$ & $32.08 \pm 3.09$ \\
\hline $\begin{array}{c}\text { Horizontal } \\
\text { diameter-1 (CD) }\end{array}$ & $\begin{array}{l}\text { Left: } 17.28-27.46 \\
\text { Right : } 16.54-28.12\end{array}$ & $\begin{array}{l}\text { Left : } 24.13 \pm 2.98 \\
\text { Right : } 23.31 \pm 2.13\end{array}$ & $24.54 \pm 2.65$ \\
\hline $\begin{array}{c}\text { Horizontal } \\
\text { diameter-2 (EF) }\end{array}$ & $\begin{array}{c}\text { Left: } 13.28-21.87 \\
\text { Right : } 13.96-19.34\end{array}$ & $\begin{array}{c}\text { Left : } 18.13 \pm 2.87 \\
\text { Right : } 16.03 \pm 2.65\end{array}$ & $16.56 \pm 2.45$ \\
\hline $\begin{array}{c}\text { Horizontal } \\
\text { diameter-3 }(\mathrm{GH})\end{array}$ & $\begin{array}{l}\text { Left: } 11.88-20.12 \\
\text { Right : } 11.14-20.54\end{array}$ & $\begin{array}{c}\text { Left : } 17.03 \pm 2.54 \\
\text { Right : } 16.13 \pm 3.01\end{array}$ & $17.09 \pm 2.75$ \\
\hline
\end{tabular}

Table 3: Morphological assessment of Glenoid cavity of

Table 2: Measurements of the parameters of glenoid cavity of scapula. $(\mathrm{N}=120$,

Left-57,right-63).

various parameters of scapula. $(\mathrm{N}=120$, Left67 ,right-53). scapula.( $N=120$, Left-57, right-63).

\begin{tabular}{|c|c|c|c|c|}
\hline Morphology & $\begin{array}{c}\text { No. of } \\
\text { Scapula }\end{array}$ & $\begin{array}{c}\text { Percentage } \\
(\%)\end{array}$ & Total & (\%) \\
\hline Type 1 & $\begin{array}{c}\text { Left: } 11 \\
\text { Right :10 }\end{array}$ & $\begin{array}{c}19.25 \\
15.9\end{array}$ & 21 & 17.5 \\
\hline Type 2 & $\begin{array}{c}\text { Left: } 28 \\
\text { Right :30 }\end{array}$ & $\begin{array}{c}49 \\
47.7\end{array}$ & 58 & 48.14 \\
\hline Type 3 & $\begin{array}{c}\text { Left: } 16 \\
\text { Right :18 }\end{array}$ & $\begin{array}{c}28 \\
28.62\end{array}$ & 34 & 28.22 \\
\hline Type 4 & $\begin{array}{c}\text { Left: 2 } \\
\text { Right :5 }\end{array}$ & $\begin{array}{c}3.5 \\
7.95\end{array}$ & 7 & 5.81 \\
\hline
\end{tabular}

vertical and antero-posterior diameters and compared with other studies. The average Superior-Inferior $(A B)$ diameter of the left side of glenoid cavity was revealed $30.93 \pm 4.10 \mathrm{~mm}$ and of the right side was $31.23 \pm 3.02$. The total mean value of $A B$ was recorded as $32.08 \pm 3.09$. The right $A B$ value was slightly higher than the left (Table 7/Figure 3). The Aigbogun et al.[9] reported the incidence of this total mean value is 36.87 \pm 3.94 while Akhtar et al [10] observed

\section{DISCUSSION}

The glenoid cavity of each scapula was observed for their status and their shapes, notches and $35.80 \pm 3.14$.. These values are being considerably higher than those obtained in our study (32.08 \pm 3.09$)$. This difference can be explained 
by the differing composition of the population examined. (Tab.7). Luis Rios Frutos [11], Sitha Piyawinijwong et al [12], had measured the $A B$ diameter of the male and female glenoid separately. The average $A B$ diameter of the male glenoid recorded by Luis Rios Frutos [11] was $36.08+2.05 \mathrm{~mm}$, and by Sitha Piyawinijwong [12] was $38.1 \pm 2.2 \mathrm{~mm}$. In our study the gender of scapula is not taken into consideration. The $A B$ diameter of the female glenoid measured by Sitha Piyawinijwong et al ${ }^{12}$ and Ozer et al [13] was $33.6+3.0 \mathrm{~mm}$ and $33.79+3.08 \mathrm{~mm}$ respectively 4,5 . These values were quite similar to those reported in the current study $(32.08 \pm 3.09$ $\mathrm{mm}$ ).

The average maximum Anterior-Posterior diameter (CD) of the glenoid Cavity was $24.54 \pm 2.65 \mathrm{~mm}$ in the current study. This value was quite similar to those reported by Akhtar et al. $(23.63 \pm 2.50 \mathrm{~mm})$ in his study. Peter et al [14], lannotti et al [15] had measured the CD diameter as $25.07 \pm 2.55$ and $29 \pm 3.2 \mathrm{~mm}$ respectively. These values are higher than obtained in our study. (Table 7/Figure 3). These variations may be due to different races and regions. The average Anterior-Posterior diameter (EF) of the glenoid cavity in current study was $16.56 \pm 2.45 \mathrm{~mm}$. It was recorded by Hina B Rajput [16] as $15.24 \pm 2.04 \mathrm{~mm}$ on the left side of scapula and $16.2 \pm 3.23 \mathrm{~mm}$ on right side. These observations are very close to our study. The average mean value of Anterior-Posterior diameter (GH) of the glenoid was $17.09 \pm 2.75 \mathrm{~mm}$ in our study. Mamatha et al [17] recorded the average $\mathrm{GH}$ diameter of the right glenoid was $16.27+2.01 \mathrm{~mm}$ and that of the left glenoid was $15.77+1.96 \mathrm{~mm}$. lannotti et al reported the mean $\mathrm{GH}$ value is $23 \pm 2.7 \mathrm{~mm}$, which were higher than observed in the current study.

In the current study, the incidence of various shapes of the glenoid cavity has been measured and compared with other studies. Various types of glenoid cavity based on their shape were observed and recorded. In our study the oval shaped (type1) glenoid cavity were found $19.25 \%$ on the left side and $15.90 \%$ on right side. The pear shaped (type2) glenoids were $47.70 \%$ on the right side and $49.00 \%$ on the left side. The inverted comma shaped (type3) with a distinct notch were recorded $28.00 \%$ on the left side and $28.62 \%$ on right side. This suggests that there is no significant difference in the presence of a notch on the right and left side. In $3.50 \%$ cases on the left side and $7.95 \%$ on the right side, there was indistinct notch on the anterior and posterior borders both (type4). (Table 3/Figure 4a, 4b, 4c, 4d). In our study the most common type of glenoid cavity were found is pear shaped (type2) followed by type 3 . The least common type was found is type 4. Our observations are very similar to the other researchers (Table 8 ). The others metric parameters of scapula like breadth, length, infraspinous length were also measured and recorded in tabulated form. The findings of the present study were compared with various studies carried out on other races. Mean Scapular length observed in present study was $130.21 \pm 12.65 \mathrm{~mm}$ which is close to the values obtained by the Akhtar et al [10]. Chhabra $\mathrm{N}$ et al [18] study showed mean scapular length of $141.94 \pm 12.76 \mathrm{~mm}$. and Singal et al [19] found of $141.7 \pm 8.9 \mathrm{~mm}$.(Fig.2, tab.4). These values were higher than the values obtained in our study. Whereas that of Coskum et al [20] were found $98.8 \pm 7 \mathrm{~mm}$, lower than the our study. This difference may have been as a result of studies carried out on different races and populations. The mean width of the scapula in the present study was recorded as $96.98 \pm 7.62 \mathrm{~mm}$. It is quite similar to finding observed by Singal et al [19] \& Peter Ericson et al [14], whereas it was recorded by the Chhabra $\mathrm{N}$ et al [18] by $103.65 \pm 6.82 \mathrm{~mm}$, higher than the value obtained in this study. The mean scapular index obtained in present study was $68.47 \pm 3.98 \mathrm{~mm}$. It was similar to Singhal et al infraspinous index of $68.5 \mathrm{~mm}$. However the findings of the present study were quite higher when compared to Turner et al. $(64.9 \mathrm{~mm})$ and lower to Krishnaiah et al [21] (73.99mm) (Tab.6). Mean Infraspinous length observed in the present study was $99.65 \pm 8.32 \mathrm{~mm}$; the findings of present study coincide with those of chhabra et al [18]. $(99.60 \mathrm{~mm})$. The knowledge of different parameters of glenoid cavity is important for the orthopaedician to resurface the glenoid cavity during total shoulder arthroplasty. The information about various parameters like scapular length, breadth etc .are important for designing implants for the shoulder joint. 
Table 4: Comparison of scapular length of this study with earlier studies.

\begin{tabular}{|c|c|c|c|}
\hline No. & Authors & $\begin{array}{c}\text { Scapula } \\
\text { observed }\end{array}$ & $\begin{array}{c}\text { Mean length of } \\
\text { scapula (mm) }\end{array}$ \\
\hline $\mathbf{1}$ & Present study & 120 & $130.21 \pm 12.65$ \\
\hline $\mathbf{2}$ & Chhabra N et al [18] & 126 & $141.94 \pm 12.76$ \\
\hline $\mathbf{3}$ & Peter Ericson et al [14] & 50 & $141.49 \pm 9.74$ \\
\hline $\mathbf{4}$ & Coskum et al [20] & 90 & $98.8 \pm 7$ \\
\hline $\mathbf{5}$ & Singal et al [19] & 162 & $141.7 \pm 8.9$ \\
\hline
\end{tabular}

Table 5: Comparison of scapular breadth of this study with earlier studies.

\begin{tabular}{|c|c|c|c|}
\hline No. & Authors & $\begin{array}{c}\text { Scapula } \\
\text { observed }\end{array}$ & $\begin{array}{c}\text { Mean length of } \\
\text { scapula(mm) }\end{array}$ \\
\hline $\mathbf{1}$ & Present study & 120 & $96.98 \pm 7.62$ \\
\hline $\mathbf{2}$ & Chhabra N et al [18] & 126 & $103.65 \pm 6.82$ \\
\hline $\mathbf{3}$ & Peter Ericson et [14] & 50 & $98.69 \pm 6.98$ \\
\hline $\mathbf{4}$ & Flower WH [22] & 200 & 101.42 \\
\hline $\mathbf{5}$ & Singal et al [19] & 162 & $96.4 \pm 7$ \\
\hline
\end{tabular}

Table 6: comparison of observed values (scapular index) of this study with other studies.

\begin{tabular}{|c|c|c|c|}
\hline No. & Authors & $\begin{array}{c}\text { Scapula } \\
\text { observed }\end{array}$ & $\begin{array}{c}\text { Mean length of } \\
\text { scapula(mm) }\end{array}$ \\
\hline 1 & Present study & 120 & $68.47 \pm 3.98$ \\
\hline 2 & Turner et al [23] & 25 & 64.9 \\
\hline 3 & Singhal et al [19] & 162 & 68.5 \\
\hline 4 & Krishnaiah et al [21] & 50 & 73.99 \\
\hline
\end{tabular}

Table 7: Comparison of the different parameters of glenoid cavity of this study with other studies(In $\mathrm{mm}$ ).

\begin{tabular}{|c|c|c|c|c|c|c|}
\hline \multirow{2}{*}{ No. } & \multirow{2}{*}{ Authors } & \multirow{2}{*}{$\begin{array}{c}\text { Scapula } \\
\text { observed }\end{array}$} & \multirow{2}{*}{$\begin{array}{c}\text { Mean SI } \\
\text { diameter }\end{array}$} & \multicolumn{3}{|c|}{ Total Mean horizontal diameter } \\
\cline { 5 - 7 } & & & & CD & EF & GH \\
\hline 1 & Present study & 120 & $32.08 \pm 3.09$ & $24.54 \pm 2.65$ & $16.56 \pm 2.45$ & $17.09 \pm 2.75$ \\
\hline 2 & Aigbogum [9] & 200 & $36.87 \pm 3.94$ & $25.15 \pm 3.60$ & - & - \\
\hline 3 & Peter et al [14] & 50 & $36.85 \pm 3.17$ & $25.07 \pm 2.55$ & - & - \\
\hline 4 & Swapna et al [24] & 50 & $36.83 \pm 3.18$ & $25.08 \pm 2.53$ & - & - \\
\hline 5 & Akhtar et al [10] & 228 & $35.80 \pm 3.14$ & $23.63 \pm 2.50$ & - & $16.17 \pm 2.24$ \\
\hline 6 & lannotti et al [15] & 140 & $39 \pm 3.5$ & $29 \pm 3.2$ & - & $23 \pm 2.7$ \\
\hline
\end{tabular}

Table 8: Comparison between shapes of the Glenoid cavity ( $N=120$, Left-57, right-63).

\begin{tabular}{|c|c|c|c|c|c|}
\hline Authors & $\begin{array}{c}\text { No. of } \\
\text { Scapula }\end{array}$ & $\begin{array}{c}\text { Type 1 } \\
\text { (\%) }\end{array}$ & $\begin{array}{c}\text { Type 2 } \\
\text { (\%) }\end{array}$ & $\begin{array}{c}\text { Type 3 } \\
\text { (\%) }\end{array}$ & $\begin{array}{c}\text { Type 4 } \\
\text { (\%) }\end{array}$ \\
\hline \multirow{2}{*}{ Present study } & Left: 57 & 19.25 & 49 & 28 & 3.5 \\
& Right :63 & 15.9 & 47.7 & 28.62 & 7.95 \\
\hline \multirow{2}{*}{ Sarwar et al [25] } & Left: 50 & 16 & 64 & 20 & - \\
& Right :50 & 20 & 56 & 24 & - \\
\hline \multirow{2}{*}{ Mamatha et al [17] } & Left: 104 & 24 & 43 & 33 & - \\
& Right :98 & 20 & 46 & 34 & - \\
\hline \multirow{2}{*}{ Rachna Agrawal [26] } & Left: 67 & 25.37 & 44.78 & 29.86 & - \\
& Right :64 & 35.94 & 50 & 14.04 & - \\
\hline \multirow{2}{*}{ Rajput et al [16] } & Left: 57 & 15 & 46 & 39 & \\
& Right :43 & 16 & 49 & 35 & - \\
\hline
\end{tabular}

To summarize, the present study provides a base line data of different scapular dimensions on the left and right sides. Knowledge of the measurements and indices of various parameters of scapula such as length, width etc. can be used for comparative anatomy and also for defining the race. These findings will also be useful during surgical procedures. Variations in the size and shape of the glenoid cavity which were observed in the current study will be helpful for orthopedic surgeons for the designing and fitting of glenoid components for total shoulder arthroplasty. It has also postulated that the glenoid cavity stability is to a reasonable extent associated with the relationship between glenoid cavity dimensions (glenoid index) than to the labrum.

\section{ACKNOWLEDGEMENTS}

We are very thankful to the colleagues and non-teaching staff and museum in charge of Department of Anatomy for their continuous support and help.

\section{Conflicts of Interests: None}

\section{REFERENCES}

[1]. Solanki BS. The Angles of Scapula. J AnatSoc India.1979;28(1):pp 16-21.

[2]. W. M. Bass, Human Osteology: A Laboratory and Field Manual, Archaeological Society, Columbia, Mo, USA, 1995.

[3]. K. L. Moore and A. F. Dalley, the Upper Limb: Clinically Oriented

[4]. Anatomy, Lippincott Williams \& Wilkins, Philadelphia, Pa, USA, 5th edition, 2006.

[5]. N. Marieb and J.Mallatt, Human Anatomy, Pearson Education, San Francisco, Calif, USA, 3rd edition, 2003.

[6]. Breathnach AS. Frazer's Anatomy of the Human Skeleton.6th ed. London: J and A Churchill Ltd; 1965;63-70.

[7]. Prescher A, Klumpen T. The glenoid notch and its relation to the shape of the glenoid cavity of the scapula. J Anat 1997;190(3):457-60.

[8]. Churchill RS, Brems JJ, Kotschi H. Glenoid size, inclination, and version: An anatomic study. J Shoulder Elbow Surg 2001;10(4):327-32.

[9]. Ebraheim NA, XuR, HamanSP, Miedler JD, YeastingRA.Quantitative anatomy of scapula. Am J Orthop (Belle Mead NJ), 2004;29(4):287-292.

[10]. Aigbogun (Jr) EO1, Oladipo GS2, Oyakhire MO3, Ibeachu PC4. Morphometry of the glenoid cavity and its correlation with selected geometric measurements of the scapula. Bangladesh Journal of Medical Science 2017;16(4). 
[11]. Md. Jawed Akhtar, Bipin Kumar, Nafees Fatima, Vinod Kumar. Morphometric analysis of glenoid cavity of dry scapulae and its role in shoulder prosthesis. Int J Res Med Sci. 2016 Jul;4(7):2770-2776

[12]. Frutos LR, Determination of sex from the clavicle and scapulae in a Guatemalan contemporary rural indigenous population. Am J Forensic Med and Pathol 2002;23:284-288.

[13]. Sitha piyawinijwong, Nopparatan sirisathira, Aporn chuncharunee, The Scapula : Osseous Dimensions and Gender Dimorphism in Thais. Siriraj Hosp Gaz 2004;56(7):356-365.

[14]. Ozer I, Katayama K, Sagir M, Gulec E. Sex determination using the scapulae in medieval skeletons from east Anatolia. Coll Anthropoll 2006;30;415419.

[15]. Peter Ericson Lingamdenne, Pavani Marapaka. Measurement and analysis of anthropometric measurements of the human scapula in telangana region, India. Int J Anat Res 2016;4(3):2677-83.

[16]. Iannotti JP, Gabriel JP, Schneck SL, Evans BG, Misra S.The normal glenohumeral relationships. An anatomical study of one hundred and forty shoulders. J Bone Joint Surg Am 1992;74:491-500.

[17]. Rajput HB, Vyas KK, Shroff BD. A Study of Morphological Patterns of Glenoid Cavity of Scapula. Natl J Med Res. 2012;2(4):504-7.

[18]. Mamatha T, Pai SR, Murlimanju BV, Kalthur SG, Pai MM, Kumar B. Morphometry of Glenoid Cavity. Online J Health Allied Scs. 2011;10(3):1-4.

[19]. Chhabra N, Prakash S, Mishra BK. Morphometric Analysis of Adult Dry Human Scapulae. International Journal of Medical and Health Research. 2015;1(2):35-38

[20]. Singhal G, Rathod H, Patel A, Modi P, Prajapati S, Parmar R. A study of measurements and indices of human scapula at Jamnagar Medical College. Int J Res Med. 2013;2(1):65-8.

[21]. Coskun N, Karaali K, Cevikol C, Demirel BM, Sindel $M$. Anatomical basics and variations of the scapula in Turkish adults. Saudi Med J. 2006;27(9):1320-5.
[22]. Krishnaiah M, Nagaraj S, Kumar P, Sherke AR. Study of scapular measurements and scapular indices of Andhra Pradesh region. IOSR-JDMS. 2014; 13(6):117120.

[23]. Flower WH, Garson JG. The scapular index as a race character in man. Journal of Anat physiol. 1879;14(1):13-7.

[24]. Transactions and proceedings of the Royal society of New Zealand, 1868-1961. http:// rsnz.natlib.govt.nz/volume/rsnz_26/ rsnz_26_00_000 470.html Accessed May 25th, 2015

[25]. Swapna R Chavan, Mehera Bhoir, Shobha Verma. A study of anthropometric measurements of the human scapula in Maharashtra, India. International Journal of Anatomy. 2017;1(2):23-26.

[26]. Sarwar MS, Diwan CV, Rahamn H, Raheman H, Moosa SM. A Morphometeric study of glenoid cavity of adult human scapula. International Journal of Recent Trends in Science and Technology. 2015;15(3):486-90.

[27]. Rachna Agrawal, Sangita chauhan, Sunny yadav, Arpita gupta, Manish singhal. Morphological study of shape of glenoid cavity of scapula. IJAMSCR. 2016;4(3).

\author{
How to cite this article: \\ Krishna Gopal, Anurag Singh, Onkar Singh, Chanchal Sharma. \\ MORPHOMETRIC EVALUATION OF GLENOID CAVITY AND OTHER \\ DIMENSIONS OF DRY HUMAN SCAPULAE. Int J Anat Res \\ 2018;6(2.3):5339-5345. DOI: 10.16965/ijar.2018.199
}

